\title{
Effects of self and cross pollination on fruit set and fruit quality of sour cherry cultivars
}

\author{
Ansari, M.1, Davarynejad, G.H.1, Tornyai, J. ${ }^{2}$, Nyéki, J. ${ }^{2}$, Szabó, Z. ${ }^{2}$ \& Soltész, M. ${ }^{2}$ \\ ${ }^{1}$ Department of Horticulture, Ferdowsi University of Mashhad Iran \\ ${ }^{2}$ University of Debrecen, Institute for Research and Development, Hungary
}

\begin{abstract}
Summary An experiment conducted using factorial based on randomized completely block design during 2005 and 2006 . Flowers of Érdi bőtermő, Érdi jubileum and Cigány meggy before anthesis and in balloon stages were isolated with paper bags from guest pollens and pollinated in appropriate time. The averages of final fruit set showed the advantage of open pollination (14.6\% fruit set) in compare with artificial self pollination (13.0\% fruit set) and natural self pollination (4.4\% fruit set). Siah mashhad sweet cherry cultivar with more than $70 \%$ overlap of flowering and $9.8 \%$ fruit set in 2005 and $17.9 \%$ in 2006 was the best among applied pollinisers for Érdi bőtermő sour cherry cultivar. Also, Siah mashhad sweet cherry with more than $50 \%$ overlap of flowering time and $25.8 \%$ fruit set was the best polliniser for Cigány megg. Among the pollinisers, Siah mashhad was the best for Érdi jubileum with more than 50\% overlap and $15.22 \%$ fruit set. Meanwhile, pollens of Siah mashhad caused the increase of fruit size in Cigány meggy cultivar. phenomenon. Pollens of Siah mashhad caused reduction in total soluble solids of Érdi bőtermő fruits, however, it does not have any significant effect on the acid rate of fruits.
\end{abstract}

Key words: Érdi bőtermő, Érdi jubileum and Cigány meggy open pollination, artificial and natural self pollination, cross pollination, total soluble solids

\section{Introduction}

First information's on sour cherry self fertility was mentioned by Magyar (1935), Maliga (1942) and Husz (1943) manuscripts. In sour cherry maximum fruit set due to self fertility could reach to $50 \%$. Amount of fruit set has been reported 64\% (Blazek et al. (1974), 55.2\%, Wocior (1976) and up to 50\% by Misic et al. (1977).

To earn enough yields in sour cherry, 25 to $30 \%$ of flowers should set fruits (Gozob et al, 1981). Percentage of fruit set in self fertile varieties may increase by cross pollination Krapf (1976). Cold and rainy weathers during blooming period have negative affects on the yield of self sterile sour cherry cultivars means that yield reduces highly. Enikeev (1973) reported that yearly variations have more salient effects on the yield of self sterile sour cherries in comparison with self fertile ones, namely, in self fertile varieties yield is stable.

In sour cherry the highest rate of fruit set reaches when flowers pollinate exactly when they are opening. Therefore pollination should occur after emasculation in balloon stage up to one to two days later

Ability of cultivars to fertilize each other could be shown only by pollination. Nyéki (1989) mentioned that fruit set obtaining from open pollination in Pandy sour cherries is low and highly variable during different seasons. He expressed there is a direct correlation between the rate of self fertility and the yield which obtains from open pollination.

Nyéki et al. (2002) showed that self sterile and highly self sterile sour cherry varieties with open pollination set $12.1 \%$ and $6.3 \%$ of fruits respectively. Meanwhile, self fertile and highly self fertile sour cherry varieties set $29 \%$ and $29.4 \%$ fruits, respectively during open pollination.

Results of Apostol, Nyéki and Szabó research during 1988-1991 showed fruit set obtains from open and self pollination is mainly related to climatic conditions and therefore highly variable during seasons and the amount of fruit set fluctuation by self pollination is higher than open pollination. They showed that results of open pollination of self sterile Pandy 7 sour cherry were more variable than self fertile cultivars. Differences between self and open pollination was between 9.8 to 25.2 percent. This fact shows the importance of honey bees even for self fertile varieties.

Open pollination of highly self fertile cultivars could lead to higher fruit set (Nyéki, 1989). Correlation between fruit set of self and open pollination was reported for the first time by Toth (1957) in plum varieties and confirmed by Szabó \& Nyéki (1987) and Szabó (1989). In addition, influence of pesticide use on flower formation and fertility of some fruit species was evaluated (Holb, 2008).

Sour cherry flowers should be pollinated during 24 hours after anther dehiscence. Later pollination could reduce the rate of fruit set (Free et al. 1964). Nyéki observations (1974) showed useful effects of artificial self pollination on fruit set even in self fertile varieties in comparison with natural self pollination. We could define pollinizer cultivars to fine and weak pollinizers according to their fertilization ability. Also, we could compare and assess the results of controlled cross pollination with open pollination. 
Stosser (1969) reported the effect of xenia in sweet cherry. Some characteristics (peel color, rough peel, strips on the peel and fruit flavor) which play rule in metaxenia are of importance.

The objective of this study was to determine suitable cultivars to be used as pollinators for Hungarian sour cherry cultivars (Érdi bőtermő, Érdi jubileum and Cigány meggy), planted under Mashhad, Iran climatic conditions

\section{Materials and methods}

The experiments were carried out (2005 and 2006) on Érdi bőtermő, Érdi jubileum and Cigány meggy sour cherry cultivars cultivated in Khorasan, Iran. Six replications in the first year (2005) and four replications during second year (2006) using factorial experiments on the based of randomization complete block design (RCBD)

Statistical analyses were carried out with the use of SAS and EXCEL software's. All observations were calculated in percentage scale (data related to final fruit set percentages), Arc-Sinus transformation was carried out on the data.

For free pollination, four branches from four sides of the tree were choosing with at least 100 flowers. In order to study the cross and self pollination for every polliniser variety, in balloon stage, four branches were choose from several maternal trees and isolated with paper bags.

Hand pollination carried out when $70 \%$ of flowers inside the bags opened. The germination of pollen grains was also studied in a solution of $10 \%$ sucrose and 15 ppm boric acid.

Final fruit set percentage in each pollination treatment including open pollination, natural and artificial self pollination and cross pollination calculated and fruits were taken to the lab for measuring.

Qualitative and quantitative characteristics such as fruit length, fruit diameter, and fruit shape index, total soluble solids and acid rate of fruits measured in the lab.

Érdi bőtermő, Érdi jubileum and Cigány meggy were used as reciprocal male and female cultivar and Siah mashhad, were used as pollendonor cultivars.

\section{Results and discussions}

Maximum fruit set due to Natural self pollination was in Érdi bőtermő, cultivar $(4.89 \%)$ and minimum fruit set was in Érdi jubileum (3.32\%). in 2006, maximum fruit set was observed in Cigány meggy cultivar (8.86\%) while Erdi jubileum $(2.21 \%)$ shows minimum percentage of fruit set.

According to Nyéki (1989) fertility groups based on fruit set after Natural self pollination, cultivars with $1.1-10 \%$ fruit set are named partially self fertile. However, Apostol (1996) put this cultivars into self fertile $(10.1-20 \%$ fruit set after natural self pollination) group.

Results derived from two years of experiments under Iran climatic conditions showed that this cultivars are partially self fertile and should consider compatible polliniser for them.

Nyéki observations (1974) showed the beneficial effects of artificial self pollination on fruit set in comparison with natural self pollination even in self fertile varieties. Average fruit set percentage in sour cherry increased up to $90 \%$ via artificial self pollination. Table 2 shows that fruit set obtained from this method of pollination ranged from $8.97 \%$ to $11.95 \%$ in Érdi jubileum during 2005.

Table 2. Final fruit set percentage of unassisted self pollination, artificial self pollination and open pollination in sour cherry cultivars during 2005 and 2006

\begin{tabular}{|l|c|c|c|c|c|c|}
\hline \multirow{2}{*}{ Cultivars } & \multicolumn{3}{|c|}{2005} & \multicolumn{3}{c|}{2006} \\
\cline { 2 - 7 } & $\begin{array}{c}\text { Natural } \\
\text { self } \\
\text { pollination }\end{array}$ & $\begin{array}{c}\text { Artificial } \\
\text { self } \\
\text { pollination }\end{array}$ & $\begin{array}{c}\text { Free } \\
\text { pollination }\end{array}$ & $\begin{array}{c}\text { Natural } \\
\text { self } \\
\text { pollination }\end{array}$ & $\begin{array}{c}\text { Artificial } \\
\text { self } \\
\text { pollination }\end{array}$ & $\begin{array}{c}\text { Free } \\
\text { pollination }\end{array}$ \\
\hline Érdi bötermö & 4.9 & 9.0 & 14.7 & 3.0 & 7.3 & 10.4 \\
\hline Cigány meggy & 4.6 & 10.8 & 13.0 & 8.9 & 28.7 & 24.4 \\
\hline Érdi jubileum & 3.3 & 11.9 & 13.5 & 2.2 & 10.5 & 12.1 \\
\hline average & 4.3 & 10.6 & 13.7 & 4.7 & 15.5 & 15.6 \\
\hline
\end{tabular}

1n 2006, results of artificial self pollination showed high percentage of fruit set (28.72\%) in Cigány meggy sour cherry which is so high in comparison with unassisted self pollination. Comparison of average fruit set obtained from artificial self pollination by natural self pollination showed the significant differences which reveals the importance of putting bee hives in the garden.

Results of free pollination are shown in table 2. 1n 2005, average fruit set of free pollination was $13.71 \%$ while during 2006; average fruit set was $15.64 \%$. According to results of Brózik \& Nyéki (1980) about ability of cultivars to set fruit after free pollination, our results represented that we should put these three cultivars (Érdi bőtermő, Érdi jubileum and Cigány meggy) to medium group (10.1-20\% fruit set after free pollination). During 2006, Cigány meggy sour cherry cultivar showed high fruit set (20.1-30\%) after free pollination. In this year the amount of fruit set by open pollination in Cigány meggy cultivar was $24.4 \%$.

Usually the average fruit set obtains from free pollination is higher than artificial self pollination, which is causes by effective pollination of bees and the existence of different pollens. Nyéki (1989) mentioned that there is a direct relation between the rates of self fertility and the yield obtains from free pollination. Higher degrees of self fertility resulted in better yield from free pollination.

Relation between self and free pollination is shown in Figure 1. This experiment confirmed the relation between self and free pollination which has shown previously by Nyéki (1974 and 1989). Accordingly, there is close relationship between fruit set of self and free pollination. 


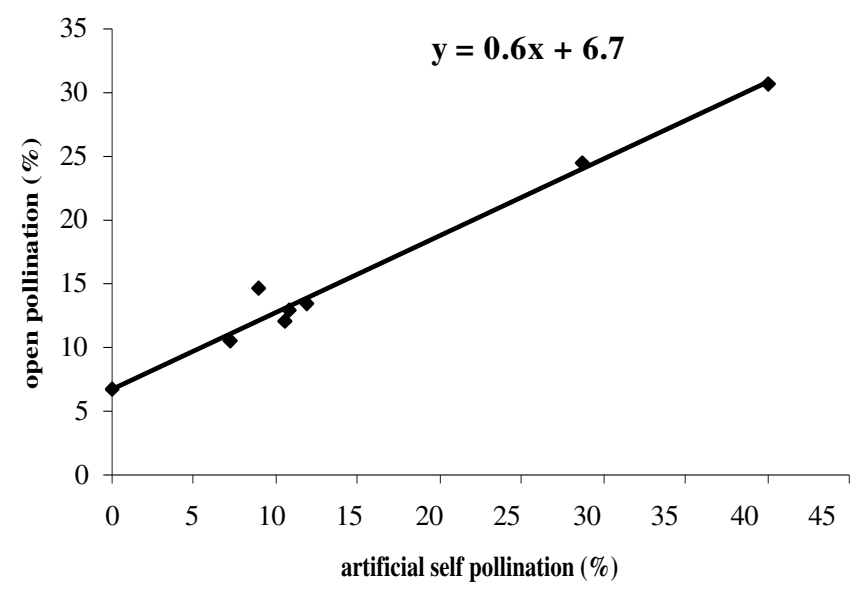

Figure 1. Correlation between artificial self pollination and free pollination in sour cherry cultivars

In self sterile and partially self fertile sour cherry cultivars, the percentage of fruit set obtain from free pollination is low. In fact there is a direct relationship between percentages of fruit set obtain from self pollination and free pollination.

\section{Cross pollination}

In this stage of experiments all three cultivars (Érdi bőtermő, Érdi jubileum and Cigány meggy) pollinated with the pollens of pollinizing cultivars (Shishei sweet cherry, siah mashhad sweet cherry, local sweet cherry, Érdi bőtermő, Érdi jubileum and Cigány meggy).

\section{Érdi bötermö sour cherry cultivar}

In 2005, there was not significant differences among the two pollendonors of Érdi bőtermő (siah mashhad with 9.86\% and local sweet cherry with $8.2 \%$ final fruit set) from the viewpoint of fertility (table 4). also the rate of fertility obtained from artificial self pollination and cross pollination with siah mashhad was not significantly different. In this year, the rate of fertility obtained from open pollination $(14.66 \%)$ was not significantly different with the result of cross pollination.

In 2006, Shishei sweet cherry cultivar caused little fruit set $(0.66 \%)$ on Érdi bőtermő according to Maliga classification (1953). In this classification, local sweet cherry, Cigány meggy and Érdi jubileum pollens could fertilize Érdi bőtermő flowers to some extent (table 4). But in this year Siah mashhad was the best pollendonor for Érdi bőtermő which caused $17.91 \%$ fruit set and showed significant difference with other pollendonors. As we seen, there is significant difference between cross pollination of Érdi bőtermő with Siah mashhad and artificial self pollination. According to Maliga (1953), we could grade Siah mashhad as medium (10.1-20\% fruit set) after cross pollination. Totally, we could introduce Siah Mashhad as a proper pollinizer for Érdi bőtermő according to synchronous flowering and the amount of fruit set.

\section{Cigány meggy sour cherry cultivar}

In 2005, among the two pollinizers used to pollinate Cigány meggy, Érdi jubileum was better with $14.27 \%$ fruit set. The other pollinizer (Érdi bőtermő) which did not show synchoronous reproductive organs activity with Cigány meggy, could not set proper fruit (9.09\%) after cross pollination.

Results of free pollination of Cigány meggy in 2006, showed the high $(24.4 \%)$ fertility. So we could place it into high fertility group in this year.

Focusing on the results of self and free pollination during 2006, it could be deducted that among the pollinizers used for Cigány meggy, Siah mashhad was the best one with $25.83 \%$ fruit set after cross pollination. Visa versa, although there was synchronous activity between reproductive organs of Érdi jubileum and Cigány meggy but the results of cross pollination (in 2006) with Érdi jubileum was not satisfactory $(12.93 \%)$

Local and Shishei sweet cherry were good pollinizers for Cigány meggy with $21.93 \%$ and $22.01 \%$ respectively. Regarding the cross pollination of Cigány meggy and Érdi bőtermő with each other, although their reproductive organs activity was not synchronous $(20 \%)$, but the results were different. The amount of fruit set on Cigány meggy sour cherry as a maternal tree after receiving the pollens of Érdi bőtermő was rather high $(9.09 \%$ and $23.72 \%$ in 2005 and 2006 respectively) in comparison with reverse combination. In 2006, when Cigány meggy were used as a pollendonor for Érdi bőtermő, it could causes only 5.79\% fruit set (Table 3).

Table 3. Final fruit set of cross pollination in sour cherry cultivars

\begin{tabular}{|l|c|c|c|c|}
\hline \multirow{2}{|c|}{ ơ $^{\prime}$} & Year & $\begin{array}{c}\text { Érdi } \\
\text { bőtermő }\end{array}$ & $\begin{array}{c}\text { Cigány } \\
\text { meggy }\end{array}$ & $\begin{array}{c}\text { Érdi } \\
\text { jubileum }\end{array}$ \\
\hline Érdi bőtermő & 2005 & - & - & - \\
& 2006 & - & $5.79 \mathrm{bcd}$ & $2.63 \mathrm{~cd}$ \\
\hline Cigány meggy & 2005 & $9.09 \mathrm{ab}$ & - & $14.27 \mathrm{a}$ \\
& 2006 & $23.72 \mathrm{ab}$ & - & $12.93 \mathrm{bc}$ \\
\hline Érdi jubileum & 2005 & $9.64 \mathrm{ab}$ & $10.53 \mathrm{ab}$ & - \\
& 2006 & $6.16 \mathrm{ab}$ & $10.84 \mathrm{ab}$ & - \\
\hline
\end{tabular}

Averages with the same letters in each column are not significantly different in $\mathrm{LSD}=0.05$

Totally among the pollinizers used for Cigány meggy cultivar, Siah mashhad sweet cherry gave the best results.

\section{Érdi jubileum sour cherry cultivar}

In 2005, when Érdi bőtermő and Cigány meggy were used as pollendonors for Érdi jubileum, there was not significant differences from the viewpoint of fertility and fruit set, but there was better overlap between Cigány meggy and Érdi jubileum. Altogether during the two years of experiments, Érdi jubileum was better pollinizer for Cigány meggy cultivar $(14.27 \%$ and $12.93 \%$ fruit set) than the time when were used Cigány meggy as pollinizer for Érdi jubileum (10.53\% and $10.84 \%$ fruit set) (table 3$)$. There was 
more than $90 \%$ overlap of flowering between these two cultivars.

Among the cultivars used as pollendonors for Érdi jubileum during 2006 (Shishei, Siah mashhad sweet cherry, Érdi bőtermő, Cigány meggy and local sour cherry), averages showed the advantage of Siah mashhad ( $15.22 \%$ fruit set). In this year, fruit set obtained from open and artificial self pollination was $12.08 \%$ and $10.52 \%$ respectively which shows the importance of fertility obtains from Siah mashhad pollinizer.

We could also consider Shishei sweet cherry as a good pollinizer for Érdi jubileum with $11.76 \%$ fruit set. According to Maliga (1953) we could classify Shishei as medium fruit set (10.1-20\%) after cross pollination.

Finally comparison of fertility relations and results of cross pollination with pollinizers, revealed that Siah mashhad sweet cherry with the average of $14.46 \%$ fruit set (table 4 ) was the best pollinizer for Hungarian sour cherry (Érdi bőtermő, Érdi jubileum and Cigány meggy) cultivars. Also we could deduct that Siah mashhad sweet cherry is the best among parental varieties used in this experiment.

\section{Qualitative and quantitative traits of fruits}

\section{Érdi bőtermő}

Cociu \& Gozob (1962) proved the effects of metaxenia phenomenon on the fruit size of sour cherry varieties. The qualitative and quantitative traits of Érdi bötermő obtained from cross pollination are shown in Table 5. Non of pollinizer cultivars have significant effect on the fruit shape of Érdi bötermő, however the fruit length and diameter belong to pollen effect of Siah mashhad but there is not any significant difference with control treatment (self pollination). If we consider artificial self pollination as control treatment, we see that none of cross pollination treatments could give satisfactory fruit quality from the viewpoint of total soluble solids (Table 5). In the case of artificial self pollination, the brix index for Érdi bőtermő is 55.16 grams per 100 grams. All cross pollination treatments showed lower brix index than control treatment (artificial self pollination).

Results showed that all cross pollination treatments partially caused reduction in total soluble solids (brix index) of Érdi bőtermő fruits (Table 5). Of course, we could not connect all innovations to the effects of metaxenia, because according to tostin et al (1988) several factors could effect on the qualitative and quantitative characteristics of fruits. For example dangle branches set lower fruits which are often smaller and with lower
Table 5. Qualitative and quantitative traits of Érdi bőtermő cultivars obtained from cross pollination with pollinizers

\begin{tabular}{|l|c|c|c|c|c|c|}
\hline \multicolumn{1}{|c|}{$\begin{array}{c}\text { Pollendonor } \\
\text { cultivars } \\
\text { shape index } \\
\text { (length/ } \\
\text { diameter) }\end{array}$} & $\begin{array}{c}\text { Fruit } \\
\text { diameter } \\
(\mathrm{mm})\end{array}$ & $\begin{array}{c}\text { Fruit } \\
\text { length } \\
(\mathrm{mm})\end{array}$ & $\begin{array}{c}\text { Total } \\
\text { soluble } \\
\text { sollids } \\
(\text { Brix*) }\end{array}$ & Acid rate* & $\begin{array}{c}\text { Final fruit } \\
\text { set }\end{array}$ \\
\hline $\begin{array}{l}\text { Shishei sweet } \\
\text { cherry }\end{array}$ & $0.88 \mathrm{a}$ & $20.63 \mathrm{abc}$ & $18.22 \mathrm{ab}$ & $90.30 \mathrm{c}$ & $114.00 \mathrm{a}$ & $0.66 \mathrm{~d}$ \\
\hline $\begin{array}{l}\text { local sweet } \\
\text { cherry }\end{array}$ & $0.85 \mathrm{a}$ & $21.43 \mathrm{a}$ & $18.25 \mathrm{ab}$ & $86.30 \mathrm{c}$ & $112.40 \mathrm{a}$ & $3.71 \mathrm{~cd}$ \\
\hline $\begin{array}{l}\text { Siah mashhad } \\
\text { sweet cherry }\end{array}$ & $0.87 \mathrm{a}$ & $21.70 \mathrm{a}$ & $18.81 \mathrm{a}$ & $91.40 \mathrm{bc}$ & $104.10 \mathrm{ab}$ & $17.91 \mathrm{a}$ \\
\hline Cigány meggy & $0.88 \mathrm{a}$ & $20.03 \mathrm{bc}$ & $17.68 \mathrm{bc}$ & $96.70 \mathrm{ab}$ & $109.90 \mathrm{ab}$ & $5.79 \mathrm{bcd}$ \\
\hline Érdi jubileum & $0.89 \mathrm{a}$ & $19.36 \mathrm{c}$ & $17.17 \mathrm{c}$ & $89.10 \mathrm{c}$ & $108.30 \mathrm{ab}$ & $2.63 \mathrm{~cd}$ \\
\hline $\begin{array}{l}\text { Érdi bőtermő } \\
\text { (self pollination) }\end{array}$ & $0.87 \mathrm{a}$ & $20.95 \mathrm{ab}$ & $18.21 \mathrm{ab}$ & $100.00 \mathrm{a}$ & $100.00 \mathrm{~b}$ & $7.26 \mathrm{bc}$ \\
\hline
\end{tabular}

Averages with the same letters in each column are not significantly different in LSD $=0.05$

$* 100 \%$ is equal to $55.16 \mathrm{gr} / 100 \mathrm{gr}$ total soluble solids and $21.1 \mathrm{gr} / 100 \mathrm{gr}$ acid quality than horizontal branches or branches with acute angle. Also, the fruit position on the tree crown hardly affects on the fruit characteristics.

About acid rate of the fruits, as we seen, cross pollination treatments such as Shishei and local sweet cherry, in addition to consequent low fertility in Érdi bőtermő, caused reduction in fruit quality via change in equilibrium between acid rate and total soluble solids of fruits.

But cross pollination of Érdi bőtermő by Siah mashhad sweet cherry resulted in rather high fertility in addition to good equilibrium between total soluble solids and acid rate of fruits. The lack of balance between total soluble solids and acid rate in fruits could causes undesired changes in fruit taste and finally reducing the marketing quality. Meanwhile, the existence of balance between the ingredients of fruits is highly important from the viewpoint of processing industry.

\section{Cigány meggy sour cherry cultivar}

Table 6 shows the results related to the effects of pollendonrs on the qualitative and quantitative traits of Cigány meggy fruits. Siah mashhad sweet cherry as 
pollinizer, had significant effect on the fruit length of Cigány meggy cultivar. The average fruit length of Cigány meggy in control treatment (artificial self pollination) was 17.05 millimeters which was 20.21 when cross pollinated with Siah mashhad pollens. In fact siah mashhad pollens leading to increase of Cigány meggy fruit size.

The comparison of total soluble solids of Cigány meggy fruits obtained from cross pollination with different pollinizers, showed the advantage of Siah mashhad compare with other pollinizers (Table 6). Although Siah mashhad pollens caused partially reduction in acid rate of Cigány meggy fruits and totally induced proper equilibrium between acid and total soluble solids of fruits.

Finally, according to the percentage of fruit set $(25.83 \%)$ and also the qualitative traits of fruits, Siah mashhad sweet cherrry was the best pollinizer for Cigány meggy sour cherry. While there was more than $50 \%$ overlap of flowering between two cultivars.

\section{Érdi jubileum sour cherry cultivar}

Results showed that pollinizers had no considerable effect on the fruit shape of Érdi jubileum sour cherry (Table 7). Pandel (1962-63) confirmed the changes in sugar and acid rate of sour cherry fruits due to metaxenia phenomenon. As we seen in Table 7, pollens of Shishei sweet cherry caused significant increase in total soluble solids of Érdi jubileum sour cherry while local sweet cherry and Cigány meggy pollens caused significant reduction. Also Shishei sweet cherry as pollinizer caused the significant reduction of acid rate of Érdi jubileum fruits. The use of Siah mashhad as paternal tree for Érdi jubileum, lead to significant reduction in acid rate of fruits in comparison with artificial self pollination. Focusing on the final fruit set obtained from cross pollination and fruit quality; in general, Siah mashhad and Shishei sweet cherry were the best pollendonor for Érdi jubileum among the pollinizers used in this experiment.

Although the final fruit set by these two pollinizers was not significantly different with the results of artificial self and open pollination.

Finally, it could be deducted from the results of natural self pollination that under Mashhad, Iran climatic conditions during 2005 and 2006, these three sour cherry cultivars (Érdi bőtermő, Érdi jubileum and Cigány meggy) classified into partially self fertile group and should consider suitable pollinizer for them. Totally, studying the results of experiment showed the high combining ability of Siah mashhad sweet cherry which could be used for improving the fertility situation abovementioned cultivars. ative traits of Cigány meggy cultivars obtained from cross pollination with pollinizers

\begin{tabular}{|l|c|c|c|c|c|c|}
\hline $\begin{array}{c}\text { Pollendonor } \\
\text { cultivars } \\
\text { shape index } \\
\text { (length/ } \\
\text { diameter) }\end{array}$ & $\begin{array}{c}\text { Fruit } \\
\text { diameter } \\
(\mathrm{mm})\end{array}$ & $\begin{array}{c}\text { Fruit } \\
\text { length } \\
(\mathrm{mm})\end{array}$ & $\begin{array}{c}\text { Total } \\
\text { soluble } \\
\text { sollids } \\
(\text { Brix*) }\end{array}$ & Acid rate* & $\begin{array}{c}\text { Final fruit } \\
\text { set }\end{array}$ \\
\hline $\begin{array}{l}\text { Shishei sweet } \\
\text { cherry }\end{array}$ & $0.88 \mathrm{~b}$ & $18.58 \mathrm{a}$ & $16.23 \mathrm{~b}$ & $93.40 \mathrm{a}$ & $90.30 \mathrm{c}$ & $22.01 \mathrm{ab}$ \\
\hline $\begin{array}{l}\text { Local sweet } \\
\text { cherry }\end{array}$ & $0.87 \mathrm{~b}$ & $20.29 \mathrm{a}$ & $17.63 \mathrm{~b}$ & $93.20 \mathrm{a}$ & $96.80 \mathrm{~b}$ & $21.93 \mathrm{ab}$ \\
\hline $\begin{array}{l}\text { Siah mashhad } \\
\text { sweet cherry }\end{array}$ & $1.00 \mathrm{a}$ & $20.21 \mathrm{a}$ & $20.21 \mathrm{a}$ & $102.80 \mathrm{a}$ & $97.80 \mathrm{~b}$ & $25.83 \mathrm{a}$ \\
\hline Érdi bötermö & $0.87 \mathrm{~b}$ & $19.48 \mathrm{a}$ & $17.02 \mathrm{~b}$ & $97.20 \mathrm{a}$ & $84.90 \mathrm{~d}$ & $23.72 \mathrm{ab}$ \\
\hline Érdi jubileum & $0.89 \mathrm{~b}$ & $18.50 \mathrm{a}$ & $16.38 \mathrm{~b}$ & $91.30 \mathrm{a}$ & $102.20 \mathrm{a}$ & $12.93 \mathrm{~b}$ \\
\hline $\begin{array}{l}\text { Cigány meggy } \\
\text { (self pollination) }\end{array}$ & $0.85 \mathrm{~b}$ & $19.95 \mathrm{a}$ & $17.05 \mathrm{~b}$ & $100.00 \mathrm{a}$ & $100.00 \mathrm{ab}$ & $28.72 \mathrm{a}$ \\
\hline
\end{tabular}

Averages with the same letters in each column are not significantly different in LSD $=0.05$

Table 7. Qualitative and quantitative traits of Érdi jubileum cultivars obtained from cross pollination with pollinizers

\begin{tabular}{|l|c|c|c|c|c|c|}
\hline \multicolumn{1}{|c|}{$\begin{array}{c}\text { Pollendonor } \\
\text { cultivars }\end{array}$} & $\begin{array}{c}\text { Fruit } \\
\text { shape index } \\
\text { (length/ } \\
\text { diameter) }\end{array}$ & $\begin{array}{c}\text { Fruit } \\
\text { diameter } \\
(\mathrm{mm})\end{array}$ & $\begin{array}{c}\text { Fruit } \\
\text { length } \\
(\mathrm{mm})\end{array}$ & $\begin{array}{c}\text { Total } \\
\text { soluble } \\
\text { sollids } \\
(\text { Brix*) }\end{array}$ & Acid rate* & $\begin{array}{c}\text { Final fruit } \\
\text { set }\end{array}$ \\
\hline $\begin{array}{l}\text { Shishei sweet } \\
\text { cherry }\end{array}$ & $0.86 \mathrm{a}$ & $21.01 \mathrm{a}$ & $18.12 \mathrm{a}$ & $106.60 \mathrm{a}$ & $88.00 \mathrm{de}$ & $11.76 \mathrm{ab}$ \\
\hline $\begin{array}{l}\text { local sweet } \\
\text { cherry }\end{array}$ & $0.85 \mathrm{a}$ & $20.24 \mathrm{a}$ & $17.13 \mathrm{a}$ & $92.90 \mathrm{~cd}$ & $104.40 \mathrm{a}$ & $10.21 \mathrm{ab}$ \\
\hline $\begin{array}{l}\text { Siah mashhad } \\
\text { sweet cherry }\end{array}$ & $0.84 \mathrm{a}$ & $20.81 \mathrm{a}$ & $17.40 \mathrm{a}$ & $98.40 \mathrm{bc}$ & $90.20 \mathrm{~cd}$ & $15.22 \mathrm{a}$ \\
\hline Érdi bőtermő & $0.85 \mathrm{a}$ & $21.09 \mathrm{a}$ & $18.04 \mathrm{a}$ & $94.40 \mathrm{bcd}$ & $85.20 \mathrm{e}$ & $6.16 \mathrm{ab}$ \\
\hline Cigány meggy & $0.86 \mathrm{a}$ & $20.21 \mathrm{a}$ & $17.42 \mathrm{a}$ & $90.40 \mathrm{~d}$ & $92.30 \mathrm{c}$ & $10.84 \mathrm{ab}$ \\
\hline $\begin{array}{l}\text { Érdi jubileum } \\
\text { (self pollination) }\end{array}$ & $0.85 \mathrm{a}$ & $20.40 \mathrm{a}$ & $17.42 \mathrm{a}$ & $100.00 \mathrm{~b}$ & $100 \mathrm{~b}$ & $10.52 \mathrm{ab}$ \\
\hline
\end{tabular}

Averages with the same letters in each column are not significantly different in LSD $=0.05$ $* 100 \%$ is equal to $80.19 \mathrm{gr} / 100 \mathrm{gr}$ total soluble solids and $83.10 \mathrm{gr} / 100 \mathrm{gr}$ acid

\section{References}

Apostol, J-né, Brózik, S. \& Nyéki, J. (1977): (In: Nyéki, J. and M. Soltész (eds.)) Floral biology of temperate zone fruit trees and small fruits.

Apostol. J. (1996): Sour and sweet cherry breeding and production in Hungary. Acta Hort., 410: 101-106.

Blazek, J., Kloutvor, J. \& Drobkova, R. (1974): Zhodnoceni autofertility v svetoveho sortimentu visni. Sbornik Uvti-genetika a slechteni., 10 (2): 139-145.

Brózik, S., Nyéki, J. \& Soltész, M. (1980): Sour cherry. (In: Nyéki. J. (ed.) Gyümölcsfajták virágzásbiológiája és termékenyülése (Bloom biology and fertility of fruit cultivars). Mezőgazdasági Kiadó, 229-233.

Brózik, S. \& Nyéki, J. (1979): Ergebnissebefruchtungsbiologischer untersuchungen bei sauerkirschen. Tag. Ber. Akad. Landwirtsch.

Cociu,V. \& Gozob,T. (1962): (In: Nyéki, J. and M. Soltész (eds.): Floral biology of temperate zone fruit trees and small fruits. 
Enikeev, H.K. (1973): K voproszu o vuvedenii szamofertilnun szortov visni (Cerasus vulgaris Mill.) v centralnun oblasztjan sz. sz. sz. R. szelszkohozj. Biologia., 8: 370-373.

Free, J.B. \& Spencer-Booth, J. (1964): The foraging areas of honey-bee colonies in fruit orchards. J. Hort. Sci., 49: 301-304.

Holb, I.J. (2008): Influence of pesticide use on flower formation and fertility of some fruit species. Int. J. Hort. Sci., 14 (1-2): 103-106.

Husz, B. (1943): (In: Nyéki, J. and M. Soltez (eds.): Floral biology of temperate zone fruit trees and small fruits.)

Krapf, B. (1976): Die befruch tungsverhaltnisse der obstbaume. Mitt. Eidg. Forschungs. Obst-und Weinbau., 133: 156-158.

Magyar, Gy. (1935): (In: Nyéki, J. and M. Soltez (eds.): Floral biology of temperate zone fruit trees and small fruits.)

Maliga, P. (1942): Adatok a Pándy meggy virágbiologiájához. M. Kir. Kert. Akad. Közl., 8: 3-5.

Maliga, P. (1953): (In: Nyéki, J. and M. Soltész (eds.): Floral biology of temperate zone fruit trees and small fruits.)

Misic, P. O., Todorovic, P.R., Lekic, N.K. \& Pavlovic, C.V. (1977): Samooplodnj u visnje. Nauka u praksi., 7: 141-144.
Nyéki, J. (1974): Flowering and fertilization of sour cherry cultivars. PhD Thesis. Hung. Aead. Sci., Budapest

Nyéki, J. (1989): Flowering and fertility in Stone fruits. DSc Thesis. Acad. Sci. Hung., Budapest

Nyéki. J., Szabó, T. \& Szabó, Z. (2002): Blooming phenology and fertility of sour cherry cultivars selected in Hungry. I.J.H.S., 8 (2): 33-37.

Stösser, R. (1966): Befruchtungsbiologische und embryologische Untersuchungen bei der Susskirsche (Prunus avium L.). Thesis, Londw. Hochschule, Stuttgart-Hohenheim,112.

Szabó, Z. \& Nyéki, J. (1987): Szilvafajták társítása. Lippay János Tudományos Ülésszak előadasai. Kertészeti és Élelmiszeripari Egyetem kiadványai, 1: 451-462.

Szabó, Z. (2002): Csonthéjas gyümölcsök termésbiztonságának egyes tényezői. Thesis. Budapest.

Tóth, E. (1957): Élet- és alaktani összehasonlító vizsgalatok szilvafajtákon. Kertészeti Kutató Intézet Évkönyve, 2: 11-129.

Wocior, S. (1976): Badania nad wybranymi zagadnieniami biologii kwitplodnosti wisni. Rozn. Nauk. Roln.,101 (3): 7-16. 